\title{
4 \\ The self-portrait and the film and video essay
}

\author{
John Conomos
}

The world is but a perennial movement. All things in it are in constant motion ... I cannot keep my subject still ... I do not portray being, I portray passing $\ldots{ }^{1}$

\section{Born under a Claude Neon milk-bar sign}

This essay seeks to illuminate the intertwined forms of the essay and the self-portrait and does so in light of recent currents in contemporary art, film, and literary and media theory. Today we can speak not only of the essay film but also of the video essay and, more generally, of the essayistic in postmodern digital creativity. As a media artist, I have always been attracted to the essay form because of its pliable, intertextual capacity to act, as Serge Daney would have it, as a 'go-between', linking cinema, video, new media, literature and critical theory. ${ }^{2}$ I have been fascinated with the idea of

\footnotetext{
1 Michel de Montaigne, 'Of repentance', in The complete essays, trans. MA Screech, London, Penguin, 1993.

2 For a more elaborate discussion of Serge Daney's idea of a filmmaker, artist and writer as a 'go-between', and the broader implications for contemporary art, cinema and literature, see John Conomos, Mutant media, Sydney, Artspace/Power Publications, 2008. And for the actual concept of 'go-between' as defined by Daney see his Postcards from the cinema, trans. Paul Grant, London and New York, Berg, 2007.
} 
cinema, video and installation as writing. The phantasmatic notion of film and video as a form of sound-image-performance-writing has haunted me since the 1960s (think of the work of Chantal Akerman, Jean Cocteau, Jean-Luc Godard, Chris Marker, Agnes Varda, Yvonne Rainer and Orson Welles). ${ }^{3}$ Over many years I have made videos, films, installations and radio as a diasporic Greek-Australian subject in postwar Australia. I have sought to create audio-visual self-portraits in the French New Wave tradition of Alexandre Astruc's key concept of caméra-stylo cinema. ${ }^{4}$

Autobiography, landscape, memory, time and the self-portrait have been interrelated concerns of my art and writing practice since the 1970s. And over the years the self-portrait has been particularly central to my videotapes, media installations, radiophonic essays and photoperformance. This (post)modern genre par excellence of image-making is emblematic of the underlying conceptual, formal and technological ideas, contexts and forms that have emerged since the historical avantgarde. As artist and writer, I have been substantially engaged with creating 'in-between' contexts, ideas and genres that emanate from art, cinema, literature, philosophy and critical theory. Indeed, it is because I have been excavating precisely these very art forms, figures and contexts that I have been able to engage in an autobiographical/ critical project over the last four decades.

But it is not that simple, for I am also critically interested in questions of seeing and hearing that may hover beyond our present horizons of creative, cultural and existential possibility. The essay form has allowed me to fashion videos, films, installations and radio texts in the hope of sustaining an informed, speculative and poetic 'bordercrossing' between established art forms and more recent forms that are particularly salient to contemporary art. In other words, I have pursued the production of trans-media work that critiques the binary essentialism of (post)modernism and western thought. At the outset, it should be observed that the increasingly compelling terrain of essayistic cinema (including the diary film, the notebook film and

3 For a discussion of the general concept of cinema, video and new media as a kind of imagesound-performance-writing as it may apply to the works of Jean-Luc Godard, Orson Welles, Chris Marker, Jean Cocteau and Agnes Varda, see Conomos, 2008.

4 For a clear and concise introduction to Alexandre Astruc's caméra-stylo idea of a personal form of cinema in the context of the French New Wave cinema, see Richard Neupert, A history of the French New Wave cinema, 2nd edn, Madison, The University of Wisconsin Press, 2002, pp. 45-56. 
the essay film in general), video and new media is critically indebted to Michel Montaigne's concept of the literary essay, as well as to autobiography and the self-portrait in painting. Image-making in this evolving field of creativity is personal-intimate cinema/video/new media trembling with experimental risk-taking and crossing generic boundaries without need of a passport. ${ }^{5}$

I became interested in creating art that questions itself as a continuing autobiographical project and articulates an overall attempt to be selfreflexive and open-ended, a project always striving to remind us that art is power and needs always to be 'untimely', to put it in Nietzsche's terms. ${ }^{6}$ Art, for me, is anti-art. The essay form permits the artist-writer to be a self-interrogator, and the past to be recognised, crucially, as a part of the present. And yet art and writing for me share a perennially nagging, half-glimpsed striving towards an undecided elsewhere. ${ }^{7}$

It is in this critical context that the essay form in contemporary audiovisual production has given me hope. In the 1970s, while squatting in London, I encountered a 'popular front' ethos - à la Jean Renoir's Crime of Monsieur Lange - of 'in-between' creativity and living. And video was always at the centre of this. In that era of punk, people used video as art, social critique, performance and parody. Returning to Sydney in 1977, I attended several short courses on video editing and production techniques. The liquid collage and intertextual poetry of the electronic medium bewitched me. It was so calligraphically flexible - just like seeing sign-writers applying their ornate art to my parents' milk-bar window in the 1950s, advertising our coming weekly bargains. To me this was to make images as if putting pen to paper, celluloid, video and neon. Enchantment.

Our milk bar at Tempe became a Bachelardian theatre of bicultural being, dislocation, surreal reverie, silence, memory and otherness. It indelibly coloured my understanding of a poetics of 'in-between' creativity, foreignness and discordances of time and space. The milk bar as home, as an uncanny place of estrangement and wonderment,

5 This notion of 'travelling without a passport' is drawn from the work of Steve Fagin. See Peter Wollen, 'An interview with Steve Fagin', October, no. 41, Summer, 1987, p. 99.

$6 \quad$ Friedrich Wilhelm Nietzsche, Untimely Meditations, Cambridge, Cambridge University Press, 1997.

7 In this I am inspired by the work of Maurice Blanchot, Hugh Kenner and Ezra Pound. 
defined my life, as in Michel de Certeau's words, 'being in between'. I was always aware of being a hybrid alien. In grappling with and indeed surviving the cultural and ideological contradictions and fictions of my life, Stanley Cavell's idea of 'the strangeness of oneself' has resonated strongly. ${ }^{9}$ Through cunning, language, mimicry and play, I learnt to value cinephilia, difference, exilic marginality, self-reflexivity and experimentation in order to survive - to make sense of my ongoing life as a hyphenated being: Greek-Australian, artist-writer. I would cling to essays, fragments, aphorisms, quotes, digressions, autobiographies and mémoires like a marooned sailor does floating wreckage. All of my works, whether Autumn song, Album leaves, Shipwreck or The spiral of time, in their respective aesthetic, cultural and formal ways enact my interest in subjective cinemathe self-portrait and the essay film and video form.

As a reluctant, introspective child acting as a scribe for our many ethnic customers in their Kafkaesque dealings with bureaucracies - the local council, the law, education, immigration and so on-I intuitively realised that life as an immigrant, as the other, meant absurdity, solitude and vulnerability (hence also my deep interest in American film noir). Waiting for the next customer to enter through the door of the milk bar-always waiting - I would watch that doorway magically transform into a movie screen, framing a world of enchantment beyond. Busy images of passing cars, customers, shopping, screaming kids and teenagers doing their Jukebox Cindy Sherman thing - I would dearly caress every image framed by the door with my roving, fugitive eyes.

Ever since those days, I have been engaged in the risk-taking enterprise of creating 'in-between' media art and writing anchored in Rainer Maria Rilke's belief that the artist or writer is the bearer of cultural memory. ${ }^{10}$ Making memory matter: this is paramount in my praxis as an artist-scholar-writer. I create art as works against forgetting. But as we are all too aware, as individuals we often misremember art, cinema, literature and life. How much do we misremember? This question haunts all of us and is lyrically posed by one of England's

8 Michel de Certeau, The practice of everyday life, trans. Steven Rendell, Berkeley, University of California Press, 2007.

9 Stanley Cavell, A pitch of philosophy, Cambridge, MA, Harvard University Press, 1994, p. xv. 10 Raymond Bellour, Between-the-images, trans. Allyn Hardyck, Zurich, JRP/Ringier, 2011. 
great film and video essayists, Chris Petit, in his 1999 'road-movie' video essay Negative space, a homage to late, great film critic and painter Manny Farber.

Writing and making art for me is utterly compelling, ontological. I have no choice; I do not know what else to do. Kafka once described his nocturnal feverish writing as an act of 'interior emigration'. Caught between two worlds I would always read between languages, between cultures, between art forms. I have been doing this all my life; rummaging among the dustbins of various art forms, genres and cultural contexts. By existential necessity I am-in the classic European sense of the term - a 'ragpicker' ${ }^{11}$ Or if you will, I became an 'aesthetic vagabond', ${ }^{12}$ interested in the multiplying 'creative encounters $^{\prime 13}$ that have been or are taking place between art, cinema, video and the new media technologies. I am concerned with the conversations that exist between these different art forms, contexts and genres, locating, as it were, the ancients next to the moderns in the same room and seeing what might ensue (think of Octavio Paz or Michel Serres). ${ }^{14}$ For me, analogue and digital media coexist as part of a continuous dialogue of art-making.

\section{The essay film and video essay}

Writing of the audio-visual essay in film, video art and new media arts, we can trace its historical legacy to the literary, the philosophical and the photographic-from Michel Montaigne through Theodor Adorno and Walter Benjamin to James Agee and Walker Evans'

\footnotetext{
11 Walter Benjamin, The arcades project, trans. Howard Eiland and Kevin McLaughlin, Cambridge, Harvard University Press, 2002; Georg Simmel, 'The metropolis and mental life', in The sociology of Georg Simmel, New York, Free Press, 1976.

12 Jean-Louis Schefer, The engimatic body, Cambridge, Cambridge University Press, 2000, p. 4.

13 Gilles Deleuze and Félix Guattari, A thousand plateaus: Capitalism and schizophrenia, trans. Brian Massumi, London, Athlone, 1987.

14 Here I am influenced especially by Octavio Paz and Michel Serres. See, for example, Octavio Paz, On poets and others, New York, Seaver Books, 1986; Michel Serres, The troubadour of knowledge, Ann Arbour, University of Michigan Press, 1997.
} 
classic collaboration Let us now praise famous men. ${ }^{15}$ For Montaigne, the essay was an ideal vehicle for speculating aloud and testing ideas on paramount questions of life, culture, politics, human fragility and society. It also asked questions of his own subjectivity and, by focusing on the dialectical tensions between 'fact' and 'fiction', was able to contribute significantly to a highly elastic personal genre of creative thought and speculation. ${ }^{16}$ The genre has the ability to compress together, in a non-systematic fashion, such devices as collage, irony, pastiche, satire, humour and paradox.

It was, however, the German critics and philosophers of the early twentieth century who further articulated what an essay might be. ${ }^{17}$ Although it was the Hungarian Marxist Georg Lukacs who described the written essay as 'criticism as a form of art' and as a 'philosophical poem', and who thought of it as a flexible form of the 'accidental' and the 'necessary', ${ }^{18}$ it was Adorno who took up Lukacs' ideas and characterised the genre as having the key characteristics of 'luck', 'play' and 'irrationality'. Thus for Lukacs and Adorno the essay did not put forward truth claims, as did documentary film, but was characterised by its fragmentary, wandering concerns and stylistics.

The film essay was first introduced as a concept by the German experimental filmmaker Hans Richter in April 1940. ${ }^{19}$ Richter argued in his seminal text, 'The essay film: A new form of documentary film', that this new genre would allow the filmmaker to make the 'invisible' world of ideas and thoughts visible on the screen. ${ }^{20}$ The film essay would transgress the traditional concepts and forms of documentary cinema, enabling the artist/filmmaker to be irrational, contradictory, speculative and fantastic - in short, to question the binary logic of western representation in art, culture, language and society.

15 The literature on the essay film and video has started to expand in the last few years. Previously it was lean pickings for anyone interested in the subject. The following are recommended: Noral Alter, 'Translating the essay into film and installation', Visual Culture, vol. 6, no. 1, 2007, pp. 44-57; Raymond Bellour, Eye for I: Video self-portraits, New York, Independent Curators Inc., 1989; Conomos, 2008; Timothy Corrigan, The essay film, Oxford and New York, Oxford University Press, 2011; and Laura Rascaroli, The personal camera, London and New York, Wallflower Press, 2009.

16 See Alter, 2007, pp. 49-50 and Corrigan, 2011.

17 Corrigan, 2011, pp. 21-3.

18 Georg Luckacs, Soul And Form, trans. Anna Bostock, Massachusetts, Cambridge University Press, 1974.

19 Corrigan, 2011, p. 63.

20 Corrigan, 2011, p. 61. 
In the late 1940s, there were several significant turning points in the unfolding sociocultural and aesthetic formations and contexts that substantially helped to usher in the film essay, and around two decades later, the video essay. In his famous 1948 essay 'The birth of the new avant-garde: The caméra-stylo', critic, filmmaker and novelist Alexandre Astruc argued that it was quite possible for a filmmaker or an artist 'to express his thoughts, however abstract they may be, or translate his obsessions exactly as he does in the contemporary essay or novel' ${ }^{21}$ For Astruc, the filmmaker's camera could become the equivalent of the author's pen, introducing the influential concept of the caméra-stylo, which animated the auteur theory of the French New Wave- exemplified by Jean-Luc Godard-and its authorial assumptions about cinematic subjectivity.

There has been no filmmaker more intertwined with the fate of the image than Godard; no one so compelled to create a new poetics of image-making anchored in the dialectic between literature and writing and the cinema (and, more recently, video). From the beginning, Godard's involvement with cinema was with its other, which for him, from the late 1950s and early 1960s on, was television. For Godard, television represented new ways of seeing and hearing, new modalities of composition and decomposition (accelerating and slowing down the image), new strategies of mise-en-scène. In a word, television's other - 'video' or 'the electronic image' - for him signified an unexplored potential for locating new sites in the image.

Since Ici et ailleurs (1974), Godard has expanded his experimentation with the new electronic image and sound systems in order to 'redefine representation in reference to bodies, time, space and speech'. ${ }^{22}$ Godard's 'border-crossing' activity over the last three decades has taken us into a new territory of imaginative possibilities between film and video predicated on attempting to see 'not this or that, but only to see if there is something to see'. ${ }^{23}$ The 'writerly attributes' of the highly elastic video medium are ideal for Godard, and for other artists, including Robert Cahen, Thierry Kuntzel, Chris Marker, Steve

\footnotetext{
21 Corrigan, 2011, p. 65.

22 Philippe Dubois, 'Video thinks what cinema creates', in Raymond Bellour and Mary Lea Bandy (eds), Jean-Luc Godard son + image 1974-1991, New York, Museum of Modern Art, 1992, pp. 169-85.

23 Conomos, 'Border crossings: Jean-Luc Godard as video essayist', in Mutant media, 2008, pp. 133-45.
} 
Fagin and Irit Batsry, who seek to construct a poetic style of electronic image-making, influenced by Stéphane Mallarmé, among others. These artists share a sustained interest in exploring the idea of videostylo writing (following Astruc's caméra-stylo in cinema) in today's media arts.

Chris Marker, like Godard, uses video technology as a 'camera-pen' to create and think, and to interrogate the image (often archival) of history, politics, time and memory. Marker's enigmatic workfilms, travel books, imaginary film scripts, photo-novels, videos, installations, photographs and travel essays - constitutes a highly subjective voyage across the world and its labyrinthine features of faces, landscapes, objects and animals in memory, time and space. He wanders the world recording his impressions as a furtive lyrical flâneur, reporting meditative image-sound letters that chronicle life as a vertigo of space and time linked by the insane impossibility and unreliability of memory. Marker's early film essays, such as Dimanche à Pékin (1955) and Lettre de Siberie (1957), his science-fiction short La jetée (1962), as well as his more personal, epistolary works such as Sans soleil (1983), AK (1985) and Le tombeau d'Alexandre (1992), are some of the more elaborate and haunting examples of film- and videostylo creativity as 'autobiographical documentary' in contemporary audio-visual media. ${ }^{24}$

In the context of the rise of the essay film or film essay, the works of the artists I have briefly surveyed here are salient, as is the expanding significance of the essay form (both print and audio-visual) that is rapidly becoming a crucial aspect of DVDs and their supplements. ${ }^{25}$ The legacy of the essay form is highly visible and arguably it is playing an essential role in shaping today's DVD cinephilia and its attendant global media culture. As a genre, the film and video essay problematises the cultural politics of representation and knowledge production. The essayistic in our 'post-human' moving image

24 Marker's essayistic work includes influential new media contributions such as the CD-ROM Immemory, 1997. See Catherine Lupton, Chris Marker: Memories of the future, London, Reaktion Books, 2008, p. 205; Conomos, 'The spiral of time: Chris Marker and new media', in Mutant media, 2008, pp. 183-95.

25 It is interesting to note the development of the scholarly video essay phenomenon of the last two years or so. No doubt the reasons for this new pedagogic essay form are complicated, but one may be able to trace a vital link to its origins in terms of the supplements (documentaries on filmmakers and written essays, etc.) of a given DVD. This new essay form in film and media scholarship warrants further critical scrutiny. 
culture is self-reflexive in that, by its very inter-disciplinary nature, it offers its own film and video criticism. Like its distant cousin the philosophical literary essay, the film and video essay embodies crossdisciplinary concepts, forms and norms. Essentially, it does not adhere to a linear narrative trajectory, but rather is hybrid, open-ended and non-hierarchical in its pluralistic image-sound-spatial figurations. This spiralling, hesitant and introspective form of image-making connects to what Chris Marker once described as 'the imaginary country which spreads out inside us'. ${ }^{26}$

As someone who has been working in the essay form and the selfportrait (across literature, cinema and video), crossing so many different kinds of cultural, generic, linguistic and psychic borders in my life's journey has been dear to me. As Salman Rushdie once said, 'To see things plainly, you have to cross a frontier' ${ }^{27}$ Easier said than done. I have always regarded art-making (irrespective of the medium) a fugitive, elliptical enterprise that questions one's own aesthetic, cultural and epistemological baggage. The artist-writer as self-interrogator, as trickster, crosses the thresholds of multiple forms, always attempting to dig deep, to mingle things, perennially engaged in boundary-creation and boundary-crossing. ${ }^{28}$

Thus it is wise to note that the critique of amnesia as a massmediated malady of late-capitalist culture is not new in itself, as Andreas Huyssen points out. For example, witness Adorno's, Walter Benjamin's and Martin Heidegger's interwar writings on the obsession with memory and the fetish quality of mass cultural forms. ${ }^{29}$ Yet, my work as an artist and as a critic/theorist strives to underscore how today's cybernetic virus of amnesia is threatening to consume memory. This contemporary amnesia constantly blights our cultural and epistemological endeavours to speak of video art's mutating complexities in a digital age. Lamentably, this amnesia is systematically embedded in our academic, funding and museological institutions and their theoretical frameworks of interpretation. Cultural amnesia travels by way of computer-networked media in our age of hyperconsumption, information networks and global capital.

\footnotetext{
26 Marker, cited in Conomos, 2008, p. 191.

27 Salman Rushdie, Imaginary homelands, London, Granta Books, 1991, p. 125.

28 Lewis Hyde, Trickster makes the world, Edingburgh, Canongate, 2008, p. 7.

29 Andreas Huyssen, Twilight memories: Marking time in a culture of amnesia, New York, Routledge, 1995.
} 
When speaking of video art and new media, it is vital to deal with their complexities, temporalities and cultural logics. For as Hubert Damisch reminded Denis Hollier, Yves-Alain Bois and Rosalind Krauss, 'We live in a moment of suspension. Is it the end of something or the beginning of something else? ${ }^{\prime 30}$ Damisch's remarks have been profoundly salient to my critical understanding of our emergent moving-image culture. In relation to the paradoxical art form we call video, for instance, we still lack the hermeneutic ability to speak of it in a language that is as inventive as it is practised today in its mutable forms of representation-production, exhibition and critical reception. I agree with Sean Cubitt, Chris Darke, Siegfried Zielinski and Nicholas Zurbrugg, among others, that we simply do not know how to talk about video art's histories, contexts, genres and effects.

Nicholas Zurbrugg's concluding words to his incisive 1991 critique of Fredric Jameson's distorted exegesis of postmodern video and multimedia performance - that we (all of us) need to learn how to observe, analyse, interpret and evaluate the new arts of the 1980s and 1990s, and now in these first decades of the new century - lamentably have still not been heeded. ${ }^{31}$ For me, video art is not dead. Along with Zielinski and others, I maintain that we are ignorant of the art formaesthetically, archivally, curatorially and pedagogically - particularly of our own video creations since the 1970s, as they are tragically (and tiresomely) eclipsed by the Euro-American canon of the art form.

To speak of one's own art and writing practice in the context of Australian video art and new media is quite a tricky thing to do, given what Gilles Deleuze demonstrated when he persuasively spelled out the many intricate biographical, cultural, social and philosophical complexities central to the act of explaining one's self to any given audience. ${ }^{32}$ This was perfectly illustrated for me when one day in the early 1980s I watched on my television set Jean Genet being interviewed by a BBC television crew. Within minutes Genet, in his withering scatalogical way, upturned the proverbial applecart

30 See Yves-Alain Bois, Denis Hollier and Rosalind Krauss, 'A conversation with Hubert Damisch', October, Summer, 1998, p. 16.

31 Nicholas Zurbrugg, 'Jameson's complaint: Video art and the inter-textual "time-wall"', Screen, vol. 32, no. 1, Spring, 1991, pp. 16-34.

32 Gilles Deleuze and Claire Parnet, Dialogues, trans. Hugh Tomlinson and Barbara Hammerjam, New York, Columbia University Press, 1987. 
and interrogated the interviewer about the ideological fictions and limitations of what conducting an interview signifies. What was it to explain oneself to someone else via the customary 'ingrained' generic banalities of television?

I became, in Abul R JanMohamed's sense, a 'border' video-maker and theorist/writer, someone who has (regardless of their class, gender, political or historical determinations) occupied over the years a heterotopic, specular site in society. ${ }^{33}$ I found myself located in a nomadic, paradoxical space between culture and system, thereby representing a subject-as-space in the hope of delineating, critiquing and inverting the real sites of the dominant culture, someone who believes in the Nietzschean self-enabling intertextual freedoms and perspectives of 'in-between' media creativity, opening up a kind of 'creative stuttering' within language. ${ }^{34}$ I have treated image-making and writing as forms of 'travelling without a passport', as Steve Fagin would say, or as the French put it, as 'paperless'-homeless, 'without (identity) papers'. I regard both creative activities as criticalspeculative enterprises, located at the edge, always in the midst of things, suspicious of monocultural homogeneity. ${ }^{35}$

\section{8 and 1984}

In 1968, as a student at the University of New South Wales, I experienced two events that would shape the kind of artist, writer and educator engaged in media arts that I was to become. Thanks to Michael Glasheen (whose pioneering importance to Australian video art is yet to be given adequate critical and museological due), I walked into the Science Theatre - where I would take a subject in the history and philosophy of science (gratefully, I may add, in hindsight) because of the university's critical legacy to CP Snow's two-culture debate of the 1960s - and heard Buckminster Fuller speak. ${ }^{36}$

33 Abdul R JanMohamed, 'Wordliness-without-world, homelessness-as home: Toward a definition of the specular border intellectual', in Michael Sprinker (ed.), Edward Said: A critical reader, Oxford, Blackwell, 1992, p. 103.

34 Deleuze and Parnet, 1987.

35 See Wollen, 1987, p. 99.

36 CP Snow, The Two Cultures, London, Cambridge University Press, 1959. 
There he was, like Robert Crumb's Mr Natural-snowy-haired, wearing thick black glasses and a threadbare black suit, with a clutch of biros and pencils in his front jacket pocket. He spoke for close to three hours non-stop, in his swirling, vertiginous, collage-style of verbal delivery, a labyrinthine vortex of cross-disciplinary subjects: Black Mountain College poetics, architecture, modernism, atonal music, American transcendental philosophy, Zen Buddhism, John Cage, mathematics ... I was cauterised into my seat. 'What in the name of Jesus H Christ was that?', I asked myself as I left the auditorium. Today I still think about it; its reverberations are still with me.

I had a similar experience in 1984-having by this time developed some critical, self-reflexive hermeneutic tools to deal with the encounter - when I attended Gayatri Spivak's restless, pantherlike talk at the University of Sydney's Footlight Theatre during the momentous Future Fall Conference on postmodernism. Another encounter that influenced my turn to collage aesthetics had occurred, again in the Science Theatre, in 1968, when I heard French novelist and critic Michel Butor speak on Charles Baudelaire as a collagistflâneur. Michel Butor's address, like Fuller's talk, but a much quieter, modulated style of verbal presentation, opened up exciting new vistas of creative and theoretical possibility.

In more recent times, I have come to believe that one is obliged to treat the past, the present and the future as a continuing dialogue of possibilities; that we must be alive to our one shared, turning world, treating the past as integral with the present. In other words, I put the ancients next to the moderns, producing in Paz's fitting expression, 'an antiquity without dates', and see what intertextual conversations ensue. ${ }^{37}$ I simply do not believe in use-by-date orthodoxies relating to creativity and scholarship. 'Give me a pencil, a box of matches and some paper and I will create cinema for you', Godard once said. 
Consequently, I have learned to value the intertextual potential that comes from an engagement of old and new media on the same shared plane of multimedia creativity. I appreciate Serres' important characterisation of the legacy of Cartesian rationalism as a violent, totalising force in our approach to the question of the relationship between Snow's two cultures and the fate of analogue media in a postcomputer epoch. ${ }^{38}$ For Serres there are complex passages that we can traverse from one domain to another, like the difficult (but rewarding) routes that he himself as a sailor-philosopher would take between isolated islands of order in a sea of chaos - as in the Northwest Passage-from one medium to another. We must be prepared to problematise global paradigms and universal ahistorical modes of thinking; to shift our ways of knowing by negotiating complexity, disorder, uncertainty and multiplicity in everyday life.

\section{Autumn song and beyond}

Finally, in concluding this essay, I wish to say a few words about my own autobiographical videographic practice and its grounding in the aesthetic and critical historical avant-garde, contemporary art, literature and philosophy. I shall focus primarily on Autumn song, as it is emblematic of my approach to video art, and briefly refer to my more recent work, The spiral of time (2013). ${ }^{39}$

\footnotetext{
38 Michel Serres, 'Northwest Passage', in Timothy Simone, Peter Caravetta, Frank Mecklenbeerg, Brigitte Ouvry-Vial, Gregory Whitehead (eds), Oasis, New York, Semiotext(e), 1984, p. 104.

39 On Autumn song see John Conomos, Autumn song, the Kythera narratives, Sydney, Australian Regional Media, 1999. On The spiral of time and other works see Brad Buckley and John Conomos, Brad Buckley/John Conomos, Sydney, The Australian Centre for Photography, illustrated monograph, 2013.
} 


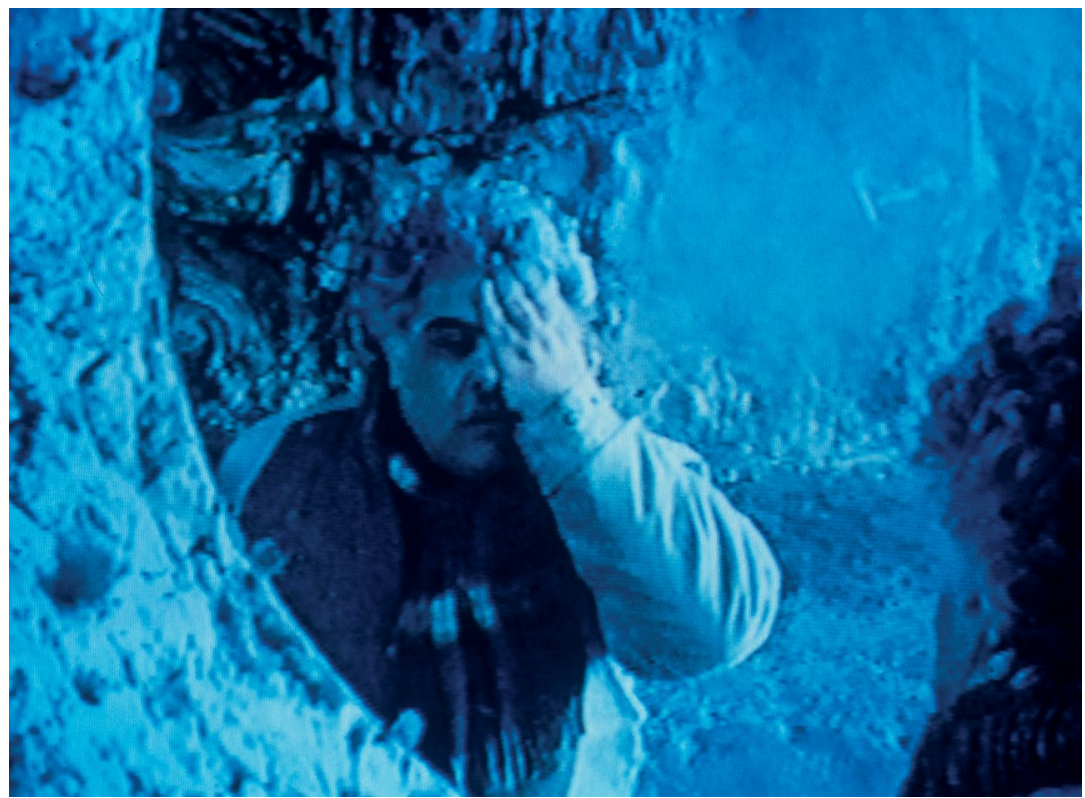

Figure 4.1: Autumn song (still), John Conomos, 1998, SP Beta, 23 mins duration.

Source: Courtesy of the artist.

The underlying narrative premise of Autumn song, as a multilayered, pun-encrusted, self-portrait video, centres on the powerful influence an uncle, Uncle Manoli, had on me as a child. He, unlike his siblings who migrated to Australia, never left the Greek island Kythera. My parents and relatives would often jokingly warn me about him - that if I wasn't careful, I'd turn out like him: a legendary, lazy, misanthropic writer with an encyclopaedic mind who spent his life in taverns playing cards. Although I didn't meet him until the 1970s (he looked like a carbon copy of my biological father, who passed away in 1957), as a child the spectre of Uncle Manoli profoundly shaped my imagination.

Autumn song's landscapes, and numerous images and quotes drawn from Man Ray, Maya Deren, Georges Franju, Buster Keaton and Chris Marker, together with its open-air performances, suggest the situation of the postcolonial alien caught between places in postwar Australia. As an autobiographical work, Autumn song engages various elaborate ideas of postcolonial dislocation, cultural mistranslation and transmigratory spaces. Its overall caméro-stylo aesthetics is 
predicated on video collage as defined in the context of cinematic and visual modernity and new media. Simply put, Autumn song, as a baroque, essayistic self-portrait, questions the surreal logic of my own (childhood) life in that it strives to problematise the conflicts, tensions and transgressive silences of my poly-cultural experience, at the same time endeavouring to define new expressive possibilities in the video medium.

One of the dominant formalistic tropes of my video weaves together references (especially in its use of film inter-titles, quotes and certain props in my improvisatory performances) to past artists, authors, filmmakers, video-makers and thinkers as a kind of antidote to the institutionalised amnesia that seems to be impacting on contemporary media's history. The voiceover (narrated by Lex Marinos) accompanying the film's improvised, playful, self-reflexive images of my childhood memories at Tempe; the numerous in situ images of me performing in the tranquil wintry landscape of Kythera (an island immortalised by Theo Angelopoulos, Baudelaire, Ernest Bloch and Claude Debussy, together with its smaller adjacent island of Anti-Kythera, which the Surrealists included in their world map); and images of me as Uncle Manoli approaches the camera with a rock, are images of the foreigner, the exiled, caught in claustrophobic spaces.

My more recent video, The spiral of time (2013), similarly focuses on my postcolonial subjectivity shaped by exile, longing and restlessness. But this work also amplifies how an existence that does not feel at home in society resonates deeply in the way one dwells within one's own body. In contrast to Autumn song's elaborate themes, sequences and meta-generic concerns, this new video is much more compressed in its allusive, speculative, collage style and concerns. It pays tribute to art, experimental/avant-garde and classical narrative cinema, contemporary and modernist literature, cultural theory and philosophy. More specifically, The spiral of time pays homage to the 'trance film' of the past, and its stark black-and-white photography evokes a netherworld of existential sleepwalking and lyrical poetry. ${ }^{40}$

40 The trance film, as a genre of European art cinema and the American avant-garde/ experimental cinema, has an elaborate aesthetic, cultural and historical genesis. Stan Brakhage, Jean Cocteau and Maya Deren are three of its key exemplars. Kenneth Anger's highly influential 'mytho-poetic' cinema is also relevant. 
Characteristically, quotations abound, drawn from the various disciplines that have shaped the basic template of my aesthetic, creative and theoretical imagination and concerns.

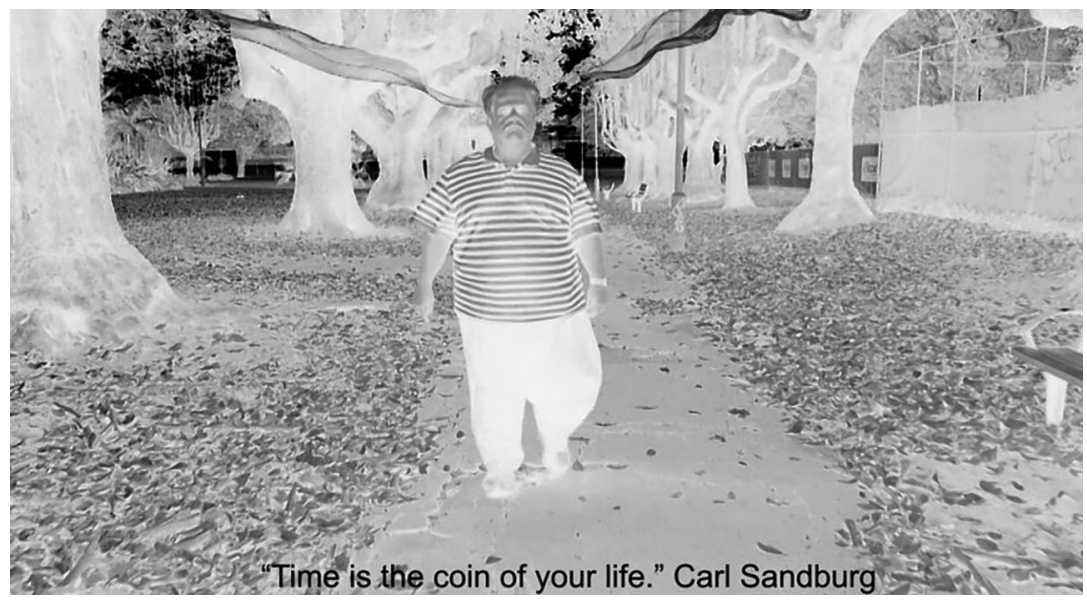

Figure 4.2: The spiral of time (still), John Conomos, 2013, HD video, 5 minutes duration.

Source: Courtesy of the artist.

To conclude, the self-portrait and essay film and video have been significant in my work as an artist, critic and educator. Ever since becoming a cinephile in the 1960s and 1970s, when the medium first surfaced in this country, I have been attracted to the untold experimental pliability of video. It was a huge leap of faith at that time, a gamble of sorts, to imagine the liminal horizons of this emerging art form. Despite the occasional 'moral panic'-charged critiques of this 'new' medium back then, its overall magnetic undertow of essayistic experimentation and critical thinking drew me into the aesthetic and literary/philosophical avant-garde of modernism, and cinema and the visual and performing arts allowed me as an image-maker, critic and writer to produce zig-zag connections between these disparate arts and disciplines. The essay form and the self-portrait gave me (and continue to do so, after 30 years) a compelling way to find new paths of articulation with my own life's autobiographical, existential and cultural horizons. 
This text is taken from Imaging Identity: Media, memory and portraiture in the digital age, edited by Melinda Hinkson, published 2016 by ANU Press, The Australian National University, Canberra, Australia. 